M. Hrgarek, D. Bartolec, I. Ružić*

\title{
STRUČNJAK ZAŠTITE NA RADU U PROCESNOJ INDUSTRIJI NEKAD I DANAS
}

UDK 66.02:331.45

PRIMLJENO: 30.12 .2019 .

PRIHVAĆENO: 28.2 .2020$.

Ovo djelo je dano na korištenje pod Creative Commons Attribution 4.0 International License

SAŽETAK: Zbog globalizacije tržišta procesna industrija postaje sve češća i važnija proizvodna grana. U odnosu na ostale proizvodne metode procesna industrija zahtijeva od svih sudionika nešto drugačiji pristup, uzimajući u obzir opseg proizvodnje, povećane rizike i velike posljedice u slučaju poremećaja procesa i nezgoda. Procesna industrija postavlja vrlo visoke zahtjeve pred stručnjaka zaštite na radu. Osim stručnih znanja iz područja zaštite na radu, stručnjak zaštite na radu u procesnoj industriji mora uzeti u obzir i specifične zahtjeve procesne industrije. Njezini zahtjevi odnose se na samu organizaciju rada, zahtjeve koje takav način rada postavlja pred zaposlenike, zahtjeve svih standarda i priznatih pravila koje je organizacija prihvatila i primjenjuje ih te zakonske zahtjeve za određeni tip industrije.

Ključne riječi: kompetencije, procesna industrija, stručnjak zaštite na radu

\section{UVOD}

Procesna industrija grana je industrije koja sve više uzima maha jer se iz nje tehnološki dobivaju osnovni materijali potrebni čovječanstvu (rude, metali, nafta i naftni proizvodi, hrana, kemijski i farmaceutski proizvodi ...). Globalizacija tržišta uzrokovala je pretvaranje maloserijske proizvodnje u velikoserijske i masovne, koristeći se novim tehnologijima koje zahtijevaju procesni pristup. U svim proizvodnim procesima koji se koriste procesnim pristupom više se ne govori o „sastavnicama materijala" već o "recepturama" kao što se umjesto "faza rada" koriste „postupci“ ili "procedure".

*Marija Hrgarek, dipl. ing. kem. tehn., (marija@ecomission.hr), Davorin Bartolec, dipl. ing. stroj., (davorin@ecomission.hr), Igor Ružić, (igor@ecomission.hr), dipl. ing. sig., EcoMission d.o.o., Zagrebačka 183, 42000 Varaždin.
U takvim uvjetima rada zaposlenici većim dijelom postaju „poslužitelji“ radne opreme, a nisu više zaduženi za upravljanje radnom opremom u smislu da određuju kad će je uključiti ili isključiti.

To znači da manje utječu na rad radne opreme, ali istovremeno moraju rad obavljati tako da radna oprema nema zastoja.

\section{METODE}

Metode korištene u izradi ovog rada su istraživanje dostupne literature i međunarodnih pravnih propisa, kompilacijom te deskriptivnom metodom na temelju podataka prikupljenih na mjestima rada u okruženju procesne industrije i izravno od sudionika u procesnoj industriji i njihove interne dokumentacije, iskustvenih podataka te analizom prikupljenih podataka. 
Izvori podataka korišteni za izradu rada navedeni su u popisu literature, a uključuju stručnu i znanstvenu literaturu, propise i norme.

\section{REZULTATI}

\section{Zaštita na radu u procesnoj industriji - povijesni pregled}

Sigurnost na radu u procesnoj industriji datira od početka 19. stoljeća kada je Du Pont u svojem pogonu za proizvodnju baruta prepoznao da čak i mali incident može izazvati znatnu štetu i gubitak života te je propisao vrlo specifične sigurnosne upute i uvjete za rad i upravljanje radnom opremom. Bez obzira na činjenicu da je procesna industrija, posebno kemijska, vrlo rano prepoznata kao visokorizična, povijest pokazuje da su nesreće $\mathrm{s}$ fatalnim ishodima u procesnoj industriji i dalje moguće čak i učestalije nego u drugim privrednim granama. Aktivnosti Američkog instituta kemijskih inženjera (AIChE) povezane sa sigurnosti kemijskih procesa proširile su se tijekom godina od prvih inicijativa koje su uključivale godišnje simpozije o sigurnosti u proizvodnji amonijaka i srodnim pogonima iz ranih 1950-ih do osnivanja Divizije za sigurnost i zdravlje pri AIChE. Nakon tragedije u Bhopalu u Indiji, AIChE je 1985. godine osnovao Centar za sigurnost kemijskih procesa (CCPS) kao industrijski savez za razmjenu informacija i poboljšanje stručnosti u vezi sa sigurnosti u procesnoj industriji. Godine 1970. osnovana je Uprava za sigurnost i zdravlje OSHA (Occupational Safety and Health Administration) koja postaje internacionalna osnova za regulativu sigurnosti na radu i zdravlje zaposlenika.

U Europi, nakon udruživanja u Europsku zajednicu, potaknuti Okvirnom Direktivom (89/391/ EEC) zemlje članice osnivaju 1994. godine Europsku agenciju za sigurnost i zdravlje na radu (EUOSHA) prema zahtjevima Regulative EZ br. 2062.

Zahvaljujući ovakvom razvoju događaja i, naravno, nacionalnim regulatorima i interesnim skupinama, započinje uvođenje pravila za pojedine industrijske grane, najprije u obliku preporuka, pa kasnije uvođenjem pravilnika, zakona te na kraju općeprihvaćenim međunarodnim propisima normama i standardima, a sigurnost i zaštita na radu postaju glavni prioritet u industriji, s krilaticom „sigurnost prije svega“.

\section{Zahtjevi procesne industrije - pregled}

Osnovna karakteristika procesne industrije je proizvodnja velikih količina gotovog proizvoda u kratkom vremenu preradom velike količine raznovrsnih ulaznih materijala s mogućnošću smanjenja jedinične cijene proizvoda. Kao glavne zahtjeve procesne industrije mogu se izdvojiti: neprekinutost procesa, produktivnost, efikasnost procesa, stabilnost procesa i kvaliteta. Navedene zahtjeve procesna industrija pokušava ispuniti propisivanjem točnih postupaka proizvodnje, skraćivanjem vremena zastoja, izbjegavanjem kvarova, uporabom prikladnijih materijala, energetskom sigurnošću te kontroliranom potrošnjom materijala i energenata.

Zastoji u procesnoj industriji uzročnici su velikih troškova te se zbog njihovog izbjegavanja, procesna industrija među prvima počela koristiti sustavima upravljanja. Danas se implementiraju norme niza ISO 9000, ISO 14000, ISO 45000, a npr. prehrambena i farmaceutska industrija implementiraju još i Good Manufacturing Practice (GMP), Hazard Analisys and Critical Control Point (HACCAP) te pravila specifična za pojedina tržišta, npr. HALAL.

\section{Odnos zaštite na radu i zahtjeva procesne industrije}

U okruženju koje iziskuje procesna industrija iznimno je teško postići zadovoljavajuće sigurne radne uvjete. Radnici se prije početka rada teoretski upoznaju s procesom preko radnih uputa u čijoj izradi sudjeluje i stručnjak zaštite na radu zbog implementacije sigurnosnih uputa. Praktično osposobljavanje radne snage provodi se pokaznim vježbama, a radnici najčešće započinju praktični rad uz nadzor mentora u stvarnim uvjetima.

Pri rukovanju radnom opremom u procesnoj industriji često su prisutne opasnosti od električne struje, mehaničke opasnosti i opasnosti od padova i rušenja. Često je radna oprema opremljena stubama, platformama, rotirajućim dijelovima, elementima s translatornim gibanjem i sl., koji su mogući uzrok nezgoda i ozljeda. Stručnjak zaštite na radu zadužen je za odabir manje opasne 
radne opreme (opskrbljene sigurnosnim elementima i sustavima) te za njezinu pravilnu montažu i ispravno i planirano održavanje koje se provodi na siguran način.

Radni okoliš u procesnoj industriji definiran je radnim postupcima, radnom opremom te pravilima dobre proizvođačke prakse i specifičnim pravilima pojedine industrijske grane. $U$ procesu projektiranja te izvođenja radova sudjeluje i stručnjak zaštite na radu koji svojim savjetima pomaže da građevine i infrastruktura budu u skladu sa zahtjevima zaštite na radu zbog izbjegavanja ili smanjenja na najmanju moguću mjeru pojave opasnosti i štetnosti u procesnoj industriji.

Izbor repromaterijala i pomoćnih materijala također je jedan od bitnih čimbenika proizvodnosti i učinkovitosti procesa u industriji te je zadaća stručnjaka zaštite na radu pružanje informacija i zalaganje za izbor neškodljivih odnosno manje štetnih materijala.

Korištenje sredstava transporta podliježe određenim pravilima koja su usko povezana sa sigurnosti i zdravljem radnika neposredno uključenih u transport i svih ostalih sudionika u prometu te osoba posredno izloženih opasnostima pri transportu. Pravila povezana s transportom (npr. ADR, ADN, RID, IMDG...) odnose se na prijevoz opasnih tvari te propisuju mehaničke karakteristike spremnika za prijevoz i sigurnosne elemente i sustave pri prijevozu, postupke pri utovaru, prijevozu i istovaru, ali također i potrebnu osposobljenost sudionika u prijevozu i obvezu označavanja takvih transporta. Transport svih ostalih materijala također podliježe zakonskoj regulativi koja propisuje određene karakteristike sredstava transporta kao i stručnu osposobljenost sudionika i obvezna označavanja pri transportima (znakovi opasnosti, zabrana i obavijesti na sredstvima transporta). Zbog svega navedenog je pri projektiranju, planiranju i provođenju aktivnosti transporta - a posebno pri kontroli, ispitivanjima i pregledima sredstava transporta i osposobljavanju sudionika uloga stručnjaka zaštite na radu od neprocjenjive koristi, sve u cilju prevencije mogućih nesreća.

Sustavi opskrbe energijom u procesnoj industriji projektiraju se kao redundantni, odnosno na način da se u slučaju kvara ili zastoja u radu jednog sustava automatski uključuje rezervni u punom ili djelomičnom opsegu potreba. To s gledišta zaštite na radu znači da opasnosti od električne struje, toplinske opasnosti i mehaničke opasnosti praktički nikad nisu isključene. Stoga je uključivanje zaštite na radu u aktivnosti projektiranja, montaže, korištenja i održavanja energetskih sustava i instalacija od velikog značaja kako bi se spriječile moguće nezgode.

Od osobnih zaštitnih sredstva svake procesne industrije uobičajeni su: zaštitne kacige, čepići za uši, rukavice, zaštitna ili higijenska odijela, kape, zaštitne naočale i druga osobna zaštitna sredstva. Posao stručnjaka zaštite na radu je da svojim znanjem i sposobnostima utječe na izbor i pruži potrebne informacije o nužnim osobnim zaštitnim sredstvima pri njihovoj nabavi, a također i da kontrolira njihovo korištenje.

Znakovi opasnosti, zabrana i obavijesti na ulazima u prostore bilo koje procesne industrije dokaz su da je u prostorima procesne industrije potreban poseban oprez. Označavanja sredstava rada (opreme i prostora) oznakama opasnosti, zabrana i obavijesti u isključivoj su nadležnosti stručnjaka zaštite na radu.

Požar i eksplozija najčešći su uzrok katastrofalnih posljedica nesreća u procesnoj industriji. Poznavanje sigurnosnih sustava, pravila sigurnosti i zaštite na radu najbitnije je za sprečavanje takvih i sličnih nesreća. Stoga je uloga stručnjaka zaštite na radu od neprocjenjive koristi pri projektiranju i korištenju tih sustava.

\section{RASPRAVA}

\section{Kompetencije stručnjaka zaštite na radu u procesnoj industriji}

lako većina naših kompanija još uvijek zapošljava stručnjake zaštite na radu na temelju zakonskih obveza, iz zahtjeva pri zapošljavanju stručnjaka zaštite na radu vanjskih kompanija, a posebno multinacionalnih, vidljivo je da tražene kompetencije daleko nadmašuju samo ekspertizu u području zaštite na radu. Nije dovoljno poznavati samo Zakon o zaštiti na radu i pripadajuće pravilnike, već se od stručnjaka zaštite na radu u procesnoj industriji zahtijeva i dobro poznavanje: 
- sustava upravljanja (niz ISO 9000, ISO 14000, ISO 45000)

- industrijskih standarda i normi (IEC, ISO, CEN, CENELEC, IEEE, NEMA, VDI)

- primjenjivih propisa (CFR, UL)

- dobre proizvođačke i inženjerske prakse (GMP, GEP)

- postupaka transporta (ADR, ADN, RID, IMDG, ICAO-TI/ATA-DGR)

- svojstava materijala, posebno opasnih

- postupaka i mjera zaštite od požara

- metoda analize opasnosti i rizika (HAZOP, What-If, HACCAP, FMEA...)

- metoda odlučivanja (Cost/Benefit, SWOT...).

Također se zahtjevi proširuju osobnim karakteristikama od kojih su svakako poželjne analitički pristup, pristup rješavanju problema, komunikativnost i spremnost na učenje.

To su općeniti zahtjevi koji se u pojedinim industrijama nadopunjuju još specifičnim znanjima, a ovisno o već implementiranim sustavima u pojedinoj kompaniji. Nadalje, dobro poznavanje funkcionalne zaštite odnosno sigurnosne opreme redovni je zahtjev koji se zahtijeva od kompetentnog stručnjaka zaštite na radu kao i određene kompetencije poznavanja i korištenja SCADA sustava odnosno standarda koji se bave tom tematikom (IEC 61508, 61511).

Svakim danom uloga stručnjaka zaštite na radu postaje sve važnija kako bi se postigao cilj - „zero accident" odnosno rad bez nesreća, a time i bez ozljeda na radu.

\section{ZAKLJUČAK}

Procesna industrija specifična je grana industrije po mnogim pokazateljima te je uloga stručnjaka zaštite na radu u procesnoj industriji iznimno zahtjevna i izazovna. Uz svoju stručnu ekspertizu u području zaštite na radu, stručnjak zaštite na radu u procesnoj industriji mora vrlo dobro poznavati i tehnologiju proizvodnje procesne industrije $u$ kojoj radi, procese logistike, procese analize i odlučivanja. Također, mora biti uključen i u sustav upravljanja procesom koji u novim izdanjima koriste procjenu rizika kao osnovu za daljnje postupanje (aktivnosti, planovi) što je prihvaćeni način rada u području zaštite na radu, te integriranje ta dva sustava kao i ISO 14000 nije problematično.

Danas stručnjak zaštite na radu mora biti multidisciplinaran, analitičan, spreman da se uhvati ukoštac s novim tehnologijama, zahtjevima, regulativom koja se stalno mijenja, radnom snagom koja postaje sve više svjesna opasnosti i štetnosti u radnom okruženju, kao i zahtjevima procesne industrije za što većom proizvodnošću i što kraćim zastojima. Jedino će na taj način moći odgovoriti na sve izazove procesne industrije i s vremenom utjecati na smanjivanje opasnosti i štetnosti koje dovode do nezgoda dok se ne postigne konačni cilj - „ZERO ACCIDENT“ proizvodnja.

\section{LITERATURA}

Hauptmanns, U.: Process and Plant Safety, Springer, Berlin, 2015.

HRN EN ISO 9001:2015, Sustavi upravljanja kvalitetom - Zahtjevi

indeed.com: Process Safety Engineer, dostupno na http://indeed.com, pristupljeno 20.10.2019.

International Organization for Standardization, dostupno na http://www.iso.org, pristupljeno 20.10.2019.

King, R., Hirst R.: Safety in the Process Industries, Butterworth-Heinemann, 1989.

Mannam, S.: Lees' Loss Prevention in the Process Industries, Elsevier, 2012.

Mary Kay O'Connor Process Safety Center, dostupno na http://psc.tamu.edu, pristupljeno 20.10.2019.

Mihailidou, E.K., Antoniadi,s K.D., Assael, M.J.: The 319 Major Industrial Accidents Since 1917, International Review of Chemical Engineering (I.RE.CH.E.), 2012., 4, str. 529-540.

Nolan, D.P.: Safety and Security Review for the Process Industries, William Andrew, USA, 2011.

Shamim, M. Y., Buang, A., Shariff, A. M. and Anjum, H.: Implementation of Safety Performance Framework (SPF), In: Process Industries to Avoid Disasters, 2018.

Zakon o zaštiti na radu, N. N., br. 71/14., 118/14., 94/14., 96/18. 


\section{OCCUPATIONAL SAFETY EXPERT IN PROCESSING INDUSTRY IN THE PAST AND TODAY}

SUMMARY: With the growing market globalization, the processing industry becomes more and more visible and important branch of production. In comparison to other types of production, the processing industry requires from all participants a slightly different approach, which takes into account the scope of production, increased risks and major consequences in case of process disturbances and accidents. The processing industry places high demands on occupational safety experts. In addition to expert knowledge in the field of occupational safety, the occupational safety experts in the processing industry must also take into account the specific requirements of the processing industry that are related to the work organization itself, the requirements that such work places on employees, the requirements imposed by the standards and recognized rules that the organization has accepted and implemented, as well as legal requirements related to a particular type of industry.

Key words: dcompetencies, processing industry, occupational safety expert

Professional paper

Received: 2019-12-30

Accepted: 2020-02-28 